\title{
New Venture Valuation and Venture Capital Perspective: An Industry Level Analysis
}

\author{
Satya Narayan Panda \\ Student, Department of Management Studies \\ INDIAN INSTITUTE OF TECHNOLOGY MADRAS \\ Chennai, Tamil Nadu, INDIA \\ Arun Kumar Gopalaswamy \\ Professor, Department of Management Studies \\ INDIAN INSTITUTE OF TECHNOLOGY MADRAS \\ Chennai, Tamil Nadu, INDIA
}

\begin{abstract}
Valuation of new venture is a key pointer for decision making for both, the entrepreneur as well as the funding venture capitalists (VC). The value depends on certain assumptions which could significantly vary from either perspective as VCs aim at enhancing stake by parting with little money and vice versa for the entrepreneur. Although there exists traditional valuation methods in corporate finance literature none are free from drawbacks when applied for startup valuations due to varied interpretations of missing accounting information, non-existence of comparable companies, problems in estimating risk and discount factors.

The objective of this research is to reduce this complexity by integrating industry structure variables in the valuation methods. As per well-established industry organization literature the industry structure variables affects firm performance. This implies that if a new venture is part of an industry characterized by high growth, high product differentiation and low concentration then the venture is expected to have adequate opportunities for superior future performance which is reflected in valuation of the firm. The empirical analysis of this research aims to identify the industry structure effects for a startup which could aid in assessing the performance and hence a robust valuation.
\end{abstract}

Keywords: Valuation, Venture Capital, Entrepreneurial Finance

\section{Introduction}

The puzzle to arrive at a single point of value from the perspective of the Venture Capitalist (VC) as well as the Entrepreneur's view is a mammoth challenge both for the 
investor and the investee. Though there has been significant research in this direction, the puzzle exits for a universally acceptable model meeting the needs of both. The focus of a $\mathrm{VC}$ is to garner maximum stake for the investment which is based on the implied value of the startup which they derive at exit. On the contrary the entrepreneur would like to part with a small stake for relatively huge investment. Therefore a mutually agreed upon valuation is the key which will aid in aligning the ambition of the entrepreneur and investors (Clercq et.al, 2006) and reduces the source of potential conflicts between entrepreneur and investor (Zacharakis, Erikson \& Bradly, 2010).

Though arriving at an accurate valuation is in the domain of financial economics, the valuation methods are based on accounting information and assumption of an efficient public capital market indicating no private information. Corporate finance literature focuses on methods such as DCF, earnings multiple, net asset, and venture capital method. On the contrary venture capital market is arguably inefficient and differs from the public capital markets on several counts (Lerner, 2000). Firstly, VC investments happen only in new and private ventures. Secondly, regulations for such investments and closely held entities are weak regarding reporting financial or management information leading to information asymmetry between entrepreneur and potential investors. Thirdly, most of the assets of these entrepreneurial firms are intangible and firm specific (Gompers and Lerner, 2001).

The inefficiency of the venture capital market makes the traditional financial valuation less satisfactory in valuing new ventures (Timmons and Spinelli, 2004). The key issue in adopting the traditional approach such as DCF for VC invested companies is in estimating future cash flows and appropriate discount rate. Firstly, young companies lack of history on revenues. Secondly, as most young companies have no publicly traded equity or bonds makes it impossible to regress the past returns, to arrive at an equity beta, or use a market interest rate on debt (Damodaran, 2009). Even adopting earnings multiple approach there are challenges such as absence of reference or comparable companies and possibility of no earnings for some new ventures. The drawback of the net assets approach is that it ignores the value of growth opportunities and, most new ventures do not have substantial level of tangible assets. Finally, the venture capital method is very subjective and valuation computed is not easy to justify (Gompers, 1999).

\subsection{Research Gap}

There is host of literature focusing on structural characteristics of industries as potential determinants of new venture performance (MacMillan, Siegel \& Narasimha, 1985; Mcdougall.et.al., 1992; Robinson, 1999 Sandberg et.al, 1987; Tsai, MacMillan \& 
Low, 1991). Despite abundant research the influence of industry structure on new venture valuation has received relatively little to no attention specifically in the context of developing economies. A possible reason could be that venture capital industry in developing economies are relatively new, creating hurdles for data or authenticity to examine the influence of industry structure on valuation of privately held firms. This research attempts to extend earlier studies on industry structure and its influence on firm performance by linking it to firm valuation in developing economy (India) context. Further the study attempts to address the gap by empirically investigating the influence of macro level non-financial industry factors which could possibly be of importance to both the groups. In addition the research also seeks to explore the possibility of developing a complementary method by providing Venture Capitalists, the variables at industry level which are less dependent on accounting information and can be objectively measured. This would aid the VCs in prioritizing the industry and also building realistic returns from investment.

To examine the influence of industry structure on valuation of new venture, the valuation of startups in India from 2006 to 2016 are analyzed. The empirical analysis presents evidence that industry structure variable, mentioned in industry organization literature, which affect firm performance can be considered as key factor in valuation. Industry characterized by firms with high product differentiation and growth are able to garner higher valuation by venture capitalists while industry concentration does not affect firm valuation. The empirical results indicate that integrating industry level variables can result in robust valuation and can help VCs in prioritizing.

Section two of this research elaborates the theoretical framework, on which hypotheses are developed. Data and research methodology are discussed in the subsequent sections followed by empirical results. This study concludes with a discussion on implications for theory and practice and by noting limitations and directions for future research.

\section{Theory and Hypotheses}

According to classical industrial Organization literature industry structure determines firms' strategies, which in turn determine firm performance. This is based on Industrial Organization (IO) theory, which elaborates, how the structure of a industry has an influence on the strategy and decision making of a firm. The industrial organization 
theory emphasizes the focus on the industry a firm operates in, rather than the firm itself (Ramsey, 2001). It is reflected in the structure-conduct-performance model in Industrial Organization literature, which claims that there is a "causal link between the structure of a market in which a company operates, the organization's conduct and in turn the organization's performance in terms of profitability" (Ramsey, 2001).

Bain (1959) stated that the most important primary structural distinctions of industries are: (1) the degree of seller concentration; (2) the extent of product differentiation to an industry. Bain (1959) also suggested that "The 'trend of demand' for industry outputwhether it is secularly growing, declining, or remaining more or less stable might offer added explanations for observed differences in market conduct and performance". Caves (1972) supported Bain's theory regarding the primary structural characteristics of industries and claimed that industry structure is important because it determines the behavior of firms in the industry. The study stated that the most important elements of industry structure are: "(1) seller concentration; (2) product differentiation; (3) barriers to the entry of new firms; and (4) growth rate of market demand". Kunkel (1991) reviewed major theoretical and empirical works on industrial organization, strategic management, and entrepreneurship to determine the relative importance of 50 industry structural variables. Based on this review, Kunkel (1991) determined that the most important industry structural variables are: (1)

Industry life cycle stage (which is related to growth rate); (2) industry concentration; (3) Industry product differentiation. Thus in this study it is proposed that structural characteristics of an industry can be considered by the venture capitalists for ascertaining expected future performance which is reflected in valuation of the firm. 


\section{Figure 1:Theoretical Framework}

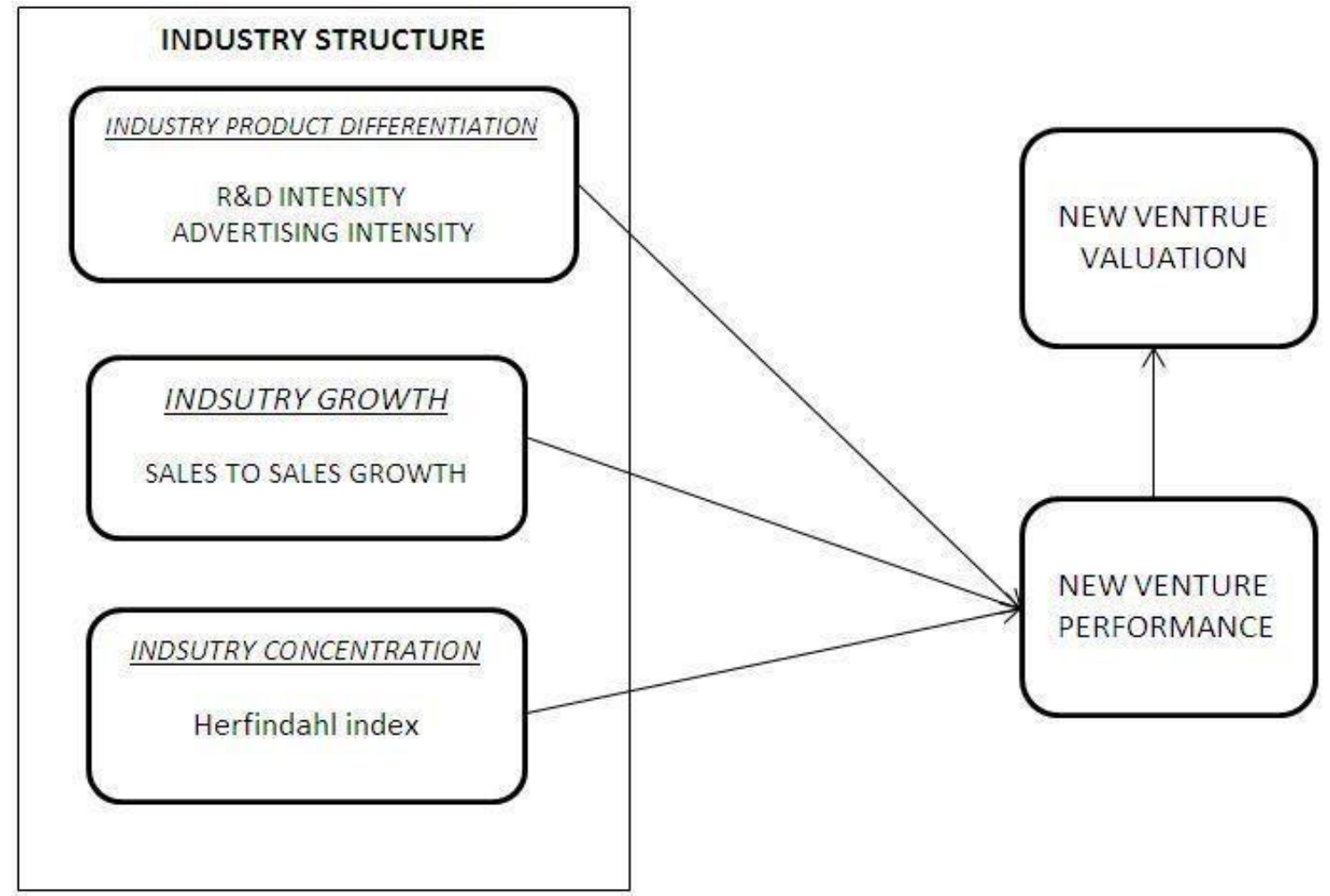

Tyebjee and Bruno (1984) was the first set of research to empirically identify the effect of industry structure on new venture performance. The study developed a five step model which lacks theoretical basis but admittedly simplistic. Based on factor analysis of responses the study found five characteristics which explained $60 \%$ of the variance in venture capitalists potential deal evaluation and among those five, market attractiveness and product differentiation had the highest effect.

MacMillan, Siegel and Narasimha (1985) intended to replicate the study reported by Tyebjee and Bruno (1984) but for a broader group of venture capitalists. The study identified high industry growth rate as the critical market requirement used by venture capitalists. Therefore venture capitalists should select the rapidly growing markets to enter where competitive pressures are less for new ventures (Miller and Camp, 1985).

Sandberg et.al (1987) built on the empirical findings of Tyebjee and Bruno (1984) and developed a model which reflected the criteria that venture capitalists used in evaluating new venture performance. It rejected the traditional academic model which argued that success of new venture performance is solely based on characteristics of entrepreneur. The empirical analysis this study found that industry structure is a key determinant in influencing new venture performance and also indicated that disregarding interactive effects on Industry structure had a greater impact on new venture performance than either strategy or the characteristics of the entrepreneur. Mcdougall et al. (1992) 
attempted to integrate the models of Sandberg (1986) with other models from strategic management, entrepreneurship literature to examine the relative explanatory power using a multivariate model of new venture strategy, industry structure, and new venture origin versus models incorporating one or a combination of two of these constructs.

Whereas Kunkel (1991)'s research findings were contrary to earlier findings with regard to importance of Industry structure explaining new venture performance. The study extended Sandberg's research by developing better description and classification systems for venture strategy/industry structure and found that Venture Strategy had a moderately strong influence on new venture performance, but Industry Structure had little influence.

Robinson (1999) focused on the influence of product differentiation on new venture performance and concluded that industry product differentiation does not have statistically significant relationships, with any alternative measures. On the contrary over $90 \%$ of the new ventures entered industries characterized by high degrees of product differentiation, indicating high degrees of product differentiation could be a necessary but not sufficient condition for achieving successful entry. Partial support for this explanation is provided by Harrigan (1981) and Yip (1982), which indicated that high degrees of product differentiation induce entry.

Shepherd (1999) attempted to investigate whether Venture capitalist's assessment policies "in use" is consistent with rigorous theoretical predictions arising form strategic literature predominantly from an industry organization perspective. The study argued based on wisdom from IO strategy researchers that a fit between the competencies of a venture and key success factors of an industry results in superior performance of new ventures occupying that industry. The study concluded considerable consistency between proposed theoretical framework and the decision policies of VCs. Such consistency suggests a potential opportunity to apply established theory in strategic management specifically from an industry organization perspective to meet the challenge of valuating a new venture accurately.

\subsection{Product Differentiation}

According to Bain (1960) the degree of product differentiation in industry refers to the extent to which buyers differentiate, distinguish, or have specific preference among the competing outputs of various sellers in a particular industry. The study claimed that product differentiation "refers to an imperfection in the substitutability which may be because of buyer's preference to certain output over others. This results in buying one output instead of others if the prices are identical and probably willing to pay a slightly 
higher amount for a preferred output (Bain, 1960). It implies that in industries with product differentiation there lies opportunity for new entrants to perform better because of non-price competition where effect of product quality and innovation are likely to be key factors.

Caves (1972) built on the arguments of Bain (1960) and contented that product differentiation support for non-price competition leading to new decisions that is based on "quality" of the product irrespective of price charged. So product differentiation affords some breathing space to firms, insulating them to some degree from price competition leading to superior firm performance.

Consistent with earlier argument, Porter (1980) stated that industries characterized by low product differentiation require new entrants to attend to cost and capacity considerations, which encourages competitive responses by incumbent firms towards these entrants, which, in turn, typically leads to decrease in profitability. Some industries, however, lend themselves to higher levels of differentiation than others, and there is evidence that industry level factors, such as overall levels of differentiation, impact performance (McGahan and Porter, 1997).

Based on the theoretical logic described, it can be argued that new venture occupied in an industry characterized by high product differentiation will have adequate opportunities, and wide scope to have superior future performance. It follows that greater expectation about future firm performance results in greater valuation by venture capitalists.

H1: Ceteris paribus, the higher the product differentiation in an industry, the higher the valuation of a new business ventures, in that industry.

\subsection{Industry Growth}

Mcdougall et al.(1994)'s study focused on industry growth as key component of industry structure and argued that growing industries are those where high demand is found and are likely to be composed of increasing numbers of firms and/or of firms with increasing on average sales revenue. Thus new ventures in high growth industries would be more successful in terms of high sales growth than new ventures in low growth industries. The empirical findings supported the argument by Porter (1980) that rapid industry growth ensures that incumbents can maintain a strong financial performance even though new entrant garners some market share. Thus, new ventures entering rapidly growing industries would provoke less retaliation by incumbent firms and suggested that ventures may experience less competitive pressures in industries with rapid growth. 
Zider(1998) argued that " One myth is that venture capitalists invest in good people and good ideas. The reality is that they invest in good industries". The study stressed that venture capitalists focus on the middle part of the classical industry S-curve. They avoid both the early stage which possess challenge of uncertain technologies and unknown market needs, and the later stage when competitive shakeouts and consolidations are inevitable and growth rate slows down dramatically.

Given the above logic it can be argued that new venture is occupied in an industry characterized by high growth is expected to perform superior resulting in higher valuation by venture capitalists. Therefore it is hypothesised as:

H2: Ceteris paribus, the growth rate of an industry is positively related to the valuation of new ventures in this industry.

\subsection{Industry Concentration}

Industry concentration represents the extent to which smaller numbers of large firms retain the dominant number of industry shares. It is one of the dominant measures of industry structure identified in industry organization literature that influence new venture entrant. When entering highly concentrated industries, the potential entrant must also consider the possibility that the established firms may collude to thwart the entry (Orr, 1974). Higher concentration allow larger firms the ability to control prices and exert monopolistic power independent of cooperation from other firms (Leach, 1997) which may create inhibition for new venture performance. Dean and Meyer (1996), based on the argument of Orr (1974), tried to establish relationship between industry concentration and new venture formation and found a significant negative relationship between them. Subsequently Biggadike (1999) supported to indicate that Ventures entering industries with low concentration ratio achieved higher ROI than those entering highly concentrated industries.

Therefore it can be argued that new venture in a low concentrated industry will have good potential and adequate opportunities to perform better. It follows that venture capitalists will, ceteris paribus, value a new Venture higher in a low concentrated because of greater expectation about future performance.

H3: Ceteris paribus, the growth rate of an industry is negatively related to the valuation of new ventures in this industry. 


\section{Research Methodology}

Given the fact that the focus is in identifying the relationships, this study has adopted a quantitative approach.

\subsection{Data Sources and case selection}

The VC valuation data is obtained from Venture Intelligence, a leading source for database on private company financials, transactions (private equity, venture capital and mergers and acquisitions) and valuations in India.

Our research focuses on the valuation of early-stage companies because these stages are most challenging for practitioners and academic researchers. Further, the characteristics of early-stage ventures are relatively easy to identify objectively.

The case selection procedures consist of the following steps: The sample firms must be / have (i) received early-stage VC funding between 1 January 2006 to 31 December 2016 (ii) Indian firms and (iii) non-financial or insurance sector. Applying these filters yielded a sample of 474 new ventures in 7 industries for the period. For industry level variable calculation the data are obtained from prowess, the data base on Indian firms maintained by the Center for Monitoring Indian Economy (CMIE).

\subsection{Measurements}

The purpose of this research is to establish the initial theoretical linkage between industry level variables and valuation, rather than on maximizing the explaining power of the model. While there are different ways to operationalize the variables in the model, the study has adopted established approaches acknowledging the constraints imposed by the availability of data.

\subsubsection{Dependent variable}

The Valuation of startup, defined as the product of the price paid per share in the financing round and the shares outstanding post the financing round, is obtained from Venture intelligence. To check for normality, Shapiro-Wilk test was used to identify deviation from normal. Since the data was not normal log transformation of the data as suggested by Gompers (1995), was adopted. Explanatory variables are described as follows.

\subsubsection{Product Differentiation}

It consists of at least two dimensions: perceptual differentiation and innovative differentiation. $R \& D$ intensity of Industry has been used a variable to capture the innovative aspect of product differentiation. $R \& D$ intensity is measured as total $R \& D$ expenditures divided by total sales revenue of an industry. 
Advertising Intensity of Industry is used to capture the perceptual aspect of product differentiation. Following Caves (1972), advertising intensity is measured as the ratio of total industry advertising expenditure to total industry sales.

\subsubsection{Industry growth}

It is measured as the percentage change of the revenue of an industry in year two (t2) over the revenue of the same industry at year one (t1).

\subsubsection{Industry Concentration}

Herfindahl-Hirschman index (HHI) was adopted for arriving at industry concentration. The index is calculated as sum of square of the market share of each firm competing in an industry.

\subsubsection{Control Variables}

To control for other relevant factors, we also include several industry level and firm level control variables in the Model which may affect valuation of new ventures. Industry Return on assets (ROA) measures the profitability of the companies in a particular industry and is calculated as the ratio of operating income to total assets of the firms in the industry. Industry Size is measured as the sum of total revenue of firms in an industry is considered as industry size. Firm Revenue is measured as the total revenue of a firm in a year.

\subsection{Model Estimation and descriptive statistics}

Summarizing the discussion, the equation below represents the model to be estimated in the empirical analyses:

Valuation of A New Venture $=\alpha+\beta_{1}($ R\&D Intensity $)+\beta_{2}($ Adv. Intensity $)+\beta_{3}$

$\left(\right.$ Industry Growth) $+\beta_{4}$ (Industrial Concentration) $+\beta_{5}$ (Industry Size) $+\beta_{6}$ (Industry ROA) $+\beta_{7}$ (Firm Revenue) where $\alpha$ is the intercept, $\beta_{1}$ to $\beta_{4}$ are the coefficients of the theoretical variables to be estimated, and $\beta_{5-7}$ represent the coefficients of the three control variables to be estimated.

For the analysis an estimate of $\log -\log$ model using pooled ordinary least square techniques is used. Industry and year dummies are included in all estimations to account for unobservable industry-specific fixed effects and macroeconomic trends in the VC market. In large cross-sectional analysis, there is always a possibility that OLS standard errors are spuriously small due to heteroskedasticity of the error term. Therefore to check for potential heteroskedasticity problem, Greene (2007) approach is adopted through modified Wald test. The result in table 1 indicates that the variances of error terms in the dependent variable are constant across observations. This indicates there is no heteroskedasticity in the data. Table 2 reports the means, standard deviations and minimum and maximum of all variables used in the model. 
Table 1. Heteroskedasticity Test

\begin{tabular}{|c|c|}
\hline \multicolumn{2}{|c|}{ Breusch-Pagan / Cook-Weisberg test for heteroskedasticity } \\
\hline \multicolumn{2}{|c|}{ Ho: Constant variance } \\
\hline Variables: fitted values of log of valuation \\
\hline chi2(1) & 0.84 \\
\hline Prob > chi2 & 0.3598 \\
\hline
\end{tabular}

Table 2. Descriptive Statistics

\begin{tabular}{|c|c|c|c|c|c|}
\hline Variable & Obs. & Mean & Std. Dev. & Min. & Max. \\
\hline Valuation(Log) & 474 & 1.5483 & 0.5227 & 0 & 3.3044 \\
\hline $\begin{array}{l}\text { Industry R\&D } \\
\text { Intensity(Log) }\end{array}$ & 474 & 0.0049 & 0.0040 & 0 & 0.0237 \\
\hline $\begin{array}{l}\text { Industry Adv. } \\
\text { Intensity(Log) }\end{array}$ & 474 & 0.0036 & 0.0027 & 0.0001 & 0.0109 \\
\hline $\begin{array}{l}\text { Industry } \\
\text { Growth(Log) }\end{array}$ & 474 & 0.0680 & 0.0363 & -0.0980 & 0.1465 \\
\hline $\begin{array}{l}\text { Industry } \\
\text { Concentration (Log) }\end{array}$ & 474 & 0.0302 & 0.0139 & 0.0044 & 0.1389 \\
\hline Industry Size(Log) & 474 & 5.3242 & 0.4440 & 3.7425 & 6.2289 \\
\hline Industry ROA(Log) & 474 & 0.0598 & 0.0245 & -0.0231 & 0.0945 \\
\hline Firm Revenue(Log) & 474 & 0.6152 & 0.4708 & 0.0043 & 2.5076 \\
\hline
\end{tabular}




\section{Analysis and Results}

Table 3 presents correlation matrix. None of the correlations are sources of concern for multi-colinearity. Table 4 reports the estimation results. Model 1 is the baseline model. Model 2 estimates the effect of all explanatory variables on valuation of new venture. 
Table 3. Correlation Matrix of all variables

\begin{tabular}{|c|c|c|c|c|c|c|c|c|}
\hline & $\begin{array}{l}\text { Valuation } \\
\text { of } \\
\text { firm(Log) }\end{array}$ & $\begin{array}{l}\text { Industry R\&D } \\
\text { Intensity(Log) }\end{array}$ & $\begin{array}{c}\text { Industry } \\
\text { Adv. } \\
\text { Intensity } \\
\text { (Log) }\end{array}$ & $\begin{array}{c}\text { Industry } \\
\text { Growth } \\
\text { (Log) }\end{array}$ & $\begin{array}{c}\text { Industry } \\
\text { Concentration } \\
\text { (Log) }\end{array}$ & $\begin{array}{c}\text { Industry } \\
\text { Size(Log) }\end{array}$ & $\begin{array}{c}\text { Industry } \\
\text { ROA(Log) }\end{array}$ & $\begin{array}{c}\text { Firm } \\
\text { Revenue } \\
\text { (Log) }\end{array}$ \\
\hline Valuation of firm & 1.0000 & & & & & & & \\
\hline $\begin{array}{l}\text { Industry R\&D } \\
\text { Intensity(Log) }\end{array}$ & 0.0386 & 1.0000 & & & & & & \\
\hline $\begin{array}{l}\text { Industry Adv. } \\
\text { Intensity(Log) }\end{array}$ & 0.0563 & 0.4720 & 1.0000 & & & & & \\
\hline $\begin{array}{c}\text { Industry } \\
\text { Growth(Log) }\end{array}$ & -0.1314 & 0.1727 & -0.0450 & 1.0000 & & & & \\
\hline $\begin{array}{c}\text { Industry } \\
\text { Concentration }(\log )\end{array}$ & -0.0522 & -0.2190 & -0.3373 & -0.0539 & 1.0000 & & & \\
\hline Industry Size(Log) & 0.0326 & -0.4874 & -0.5867 & -0.2547 & 0.1994 & 1.0000 & & \\
\hline Industry ROA(Log) & -0.0819 & -0.2855 & -0.6552 & 0.1354 & 0.3462 & 0.5763 & 1.0000 & \\
\hline
\end{tabular}




\begin{tabular}{|l|l|l|l|l|l|l|l|l|}
\hline Firm Revenue(Log) & 0.4830 & 0.0912 & 0.1567 & 0.0690 & 0.0148 & -0.2050 & -0.1707 & 1.0000 \\
\hline
\end{tabular}

No. of Observations $=474$ 
Table 4. Log of Valuation of New Ventures

\begin{tabular}{|c|c|c|}
\hline Variables & Model 1 & Model 2 \\
\hline Industry R\&D Intensity(Log) & & $0.1418(0.04910) * * *$ \\
\hline Industry Adv. Intensity(Log) & & $0.1968(0.1951)$ \\
\hline Industry Growth(Log) & & $0.0941(0.0422) * *$ \\
\hline Industry Concentration (Log) & & $-0.0086(0.0854)$ \\
\hline Industry Size(Log) & $0.3616(0.2864)$ & $-0.0934(0.3208)$ \\
\hline Industry ROA(Log) & $-0.2052(0.1600)$ & $-0.1939(0.1654)$ \\
\hline Firm Revenue(Log) & $0.2979(0.0203) * * *$ & $0.2997(0.0202)^{* * *}$ \\
\hline Year Dummies & Yes & Yes \\
\hline Time Dummies & Yes & Yes \\
\hline Intercept & $2.1081(0.6269)$ & $1.0589(0.8736)$ \\
\hline F-statistics & 16.87 & 14.73 \\
\hline P-value & 0.0000 & 0.0000 \\
\hline Adj. R Square & 0.3892 & 0.4004 \\
\hline Number of Observations & 474 & 474 \\
\hline
\end{tabular}

The primary focus is to establish a theoretical linkage between venture Capitalists' valuation of a new venture and industry structure variables derived from the industry organization literature. Here the focus is on general relationships, instead of individual coefficients. Extending the industrial Organization point of view of industry structure on firm level performance it is proposed that venture capitalists should consider the characteristics of industry structure when valuaing new venture.

$R \& D$ intensity of Industry is used to capture the innovative aspect of product differentiation and advertising intensity is used to capture the signaling aspect of product differentiation. Though R\&D intensity ratio measures of product differentiation are highly significant and are in the predicted direction, advertising Intensity measure of product differentiation is not found to be significant.

Industry growth is hypothesized to be positively and significantly related to valuation of new ventures. Consistently, industry demand growth is indeed positively and 
significantly related to valuation of new business ventures. The empirical results show that new ventures in growing industry do receive higher valuations. This result is in line of Zider's (1998) that venture capitalists value higher, new ventures in highly growing industries.

Industry concentration is hypothesized to be negatively and significantly related to the valuation of new ventures by VC. The empirical results show that though industry concentration affects firm performance; it has no significant influence on valuation of new ventures.

Results indicate that venture capitalists gives importance to innovation aspect of product differentiation and growth potential of industry in their valuation process. Ceteris paribus, if the industry has innovative and/or growth potential then firms in that industry gets higher valuation by VCs.

\section{Discussion and conclusions}

Empirical analysis indicates that industry product differentiation and growth have positive and significant influence on valuation of new venture. Considering their effect in startup, valuation process can aid in assessing performance and hence robust valuation. If a new venture is part of an industry characterized by high growth, high product differentiation then it is able to garner higher valuation. Further it is observed that industry concentration has no significant influence on valuation though it is one of the key factors as per industry organization literature affecting firm performance. This study has several implications for theory and practice. Firstly, prior research has primarily studied the effect of industry structure on new venture performance. This study attempts to extend this line of research by linking it to firm valuation in developing economy context and address the gap by investigating whether industry structure variables identified in industry organization literature can be considered as one of the key factors in valuation of new venture. The empirical results suggest that the VCs will have to focus on complementary methods along with traditional valuation methods for robust valuation of new venture.

Secondly, Dittmann, Maug and Kemper (2004)'s claimed that venture capitalists and entrepreneur can reduce the failure rate of funding agreements if they use multiple valuation methods before their negotiation process. Venture capital investors who stress on long term vision in their investment strategy seem to have an advantage over those who engage in short-term subjective bargaining strategies. Therefore giving importance to structural characteristics of industry in the valuation criteria provides a long-term vision of both the venture and of the funding provided after the venture valuation. 
Thirdly and lastly, this study has useful business policy implications. It provides venture capitalists with variables at industry level which influence the valuation of new venture. This can be used by venture capitalists in prioritizing the industry in their investment decision process and also building realistic return from investment.

This analysis is at the industry level due to the difficulty in obtaining firm level data for startups. There are other variables which are equally important such as characteristics of the venture capital firm and its relative bargaining power over the entrepreneur but are not included or controlled for in the model.

\section{References}

Bain, J. S. (1959), “Industrial Organization”, Wiley, New York, NY.

Biggadike, E.R. (1979), "Corporate Diversification: Entry, Strategy, and Growth", Harvard University Press, Cambridge, MA.

Caves, R. E. (1972), “American Industry: Structure, Conduct, and Performance (3rd ed.)", Prentice-Hall, Englewood Cliffs, NJ.

Clercq, D.,Fried, H.,Lehtonen, O. and Sapienza, H.(2006), “An entrepreneur's guide to the venture capital galaxy, Academy of Management Perspectives", Vol. 20 No.3 , pp. $90-112$.

Dale Orr (1974), “An Index of Entry Barriers and its Application to the Market Structure Performance Relationship", The Journal of Industrial Economics, Vol. 23No.1, pp. $39-49$.

Damodaran, A. (2009), "Valuing Young, Start-Up and Growth Companies: Estimation Issues and Valuation Challenges", Working paper.

Dean,T.J. and Meyer,G.D.(1996), “ Industry environments and new venture formations in U.S. manufacturing: A conceptual and empirical analysis of demand determinants", Journal of Business Venturing,Vol.11No.2,pp. 107-132.

Dittmann, I., Maug, E. and Kemper, J. (2004), "How fundamental are fundamental values? Valuation methods and their impact on the performance of German venture capitalists", European Financial Management, Vol. 10 No., pp. 609-38.

Greene, W. (2007), “Econometric analysis 6th ed.”, Prentice Hall, Englewood Cliffs, NJ. 
Gompers, P. (1995), "Optimal investment, monitoring and staging of venture capital", Journal of Finance, Vol.42,pp. 1461-1489.

Gompers, P. and Lerner, J. (2001), “The Money of Invention - How Venture Capital Creates New Wealth", Harvard Business School Press, Cambridge, MA.

Gompers, P. (1999), "A note on valuation in entrepreneurial ventures", HBS case 9298082:1-17.

Harrigan, K.D. (1981), "Barriers to Entry and Competitive Strategies", Strategic Management Journal, Vol. 2, 395-412.

Keeley, Robert H.; Punjabi, Sanjeev and Turki, Lassaad(1996), "Valuation of EarlyStage Ventures: Option Valuation Models vs. Traditional Approaches", Journal of Entrepreneurial and Small Business Finance,Vol.5 No.2,pp.115-138.

Kunkel, S.W. (1991),"The impact of strategy and industry structure on new venture performance", Doctoral Dissertation, University of Georgia.

Leach, Daniel F. (1997), “Concentration-profits monopoly vs. efficiency debate: south African evidence", Contemporary Economic Policy, XV.

Lerner, J.(2000), "Venture Capital and Private Equity: a Casebook.”, John Wiley \& Sons, New York, NY.

MacMillan, I.C., Siegel, R. and SubbaNarasimha, P.N. (1985), "Criteria used by venture capitalists to evaluate new venture proposals", Journal of Business Venturing, Vol.1, pp.119-128.

McDougall, P., Robinson, R., and DeNisi,A. (1992), "Modeling new venture performance: An analysis of new venture strategy, industry structure, and venture origin", Journal of Business Venturing, Vol. 7No.4, pp. 267-89.

McDougall, P., Covin, J., Robinson, R. and Herron, L. (1994), “The effect of industry growth and strategic breadth on new venture performance and strategy content", Strategic Management Journal, Vol.15 No.7, pp.537-554.

McGahan,A.M. and Potter, M.E.(1997),"How much does industry matter, really?", Strategic Management Journal, Vol. 18No.6/7, pp. 15-30.

Miller,A. and Camp,B.(1985), "Exploring determinants of success in corporate ventures", Journal of Business Venturing,Vol.1No.1,pp. 87-105. 
Orr,D.(1974),“An Index of Entry Barriers and its Application to the Market Structure Performance Relationship ",The Journal of Industrial Economics,Vol.23No.1,pp.39-49.

McDougall,P.P., RobinsonJr.,R.B. and DeNisi,A.S.(1992),"Modeling new venture performance: An analysis of new venture strategy, Industry structure, and venture origin”, Journal of Business Venturing,Vol.7 No.4, pp. 267-289.

Porter, M. E. (1980), “Competitive Strategy”, Free Press, New York, NY.

Ramsey, J.(2001), “The Resource Based Perspective, Rents, and Purchasing's Contribution to Sustainable Competitive Advantage", Journal of Supply Chain Management,Vol.37No.3,pp. 38-47.

Robinson,K.C.(1999), “An examination of the influence of industry structure on eight alternative measures of new venture performance for high potential independent new ventures",Vol.14No.2,pp.165-187.

Sandberg, W. R. and Hofer, C. W. (1987), "Improving new venture performance: The role of strategy, industry structure, and the entrepreneur", Journal of Business Venturing, Vol. 2, pp. 5-28.

Shepherd, D. (1999), "Venture capitalists' assessment of new venture survival.", Management Science, Vol. 45,pp.621-632.

Stuart, R. and Abetti, P.A. (1987), "Start-up ventures: Towards the prediction of initial success”, Journal of Business Venturing, Vol. 2No.3, pp. 215-230.

Timmons, J. and Spinelli,S.(2004), “New Venture Creation”, NYL McGraw-Hill/Irwin, New York.

Tsai, W. M., MacMillan,I. C. and Low, M. B.(1991), "Low, Effects of strategy and environment on corporate venture success in industrial markets", Journal of Business Venturing,Vol.6No.1,pp.9-28.

Tyebjee T. and Bruno, A. (1984), "A model of venture capitalist investment activity", Management Science, Vol. 30 No.9, pp. 1051-1066.

Woo,C.Y.Y. and Cooper,A.C.(1981), "Strategies of effective low share business “,Strategic Management Journal, Vol.2 , pp. 301-318.

Yip,G.S.(1982), “Diversification Entry: Internal Development versus Acquisition”, Strategic Management Journal, Vol. 3, pp. 331-345.

Zacharakis, A., Erikson, T. and Bradley, G.(2010), "Conflict between the VC and entrepreneur: The entrepreneurs' perspective”, Venture Capital, Vol.12,pp.109-126. Zider, B. (1998), "How venture capital works", Harvard Business Review, Vol.76No.6, pp. 
$5^{\text {th }}$ International Conference on New Ideas in Management, Economics and Accounting

Paris, France

November 2-4, 2018

131-139. 